\title{
Responding to the challenges of climate change in the Pacific Islands: management and technological imperatives
}

\author{
Patrick D. Nunn* \\ Professor of Oceanic Geoscience, Division of Geography, Faculty of Science, Technology and Environment, \\ The University of the South Pacific, Suva, Fiji Islands
}

\begin{abstract}
Pacific Island nations face similar challenges from climate change to those faced by other developing nations, yet these are exacerbated by the comparative smallness, remoteness, and archipelagic character of many of the islands. Proposed solutions to the effects of climate change in the Pacific Islands have often been uncritically imposed from elsewhere and have often proved unsuited to both their environmental and cultural contexts. Effective solutions to challenges of climate change in the Pacific Islands should acknowledge their unique environmental characteristics, particularly their high insularity (coastal length to land area) ratios, their topographic and geological diversity, and the raw materials available to support adaptation. It is important for policy makers to understand the cultural influences that have helped shape current environmental decision making, and the ways in which adaptations to climate change can be sustained. The efficacy of donor preferences for aid funding of policy development (top-down) rather than empowering community-level decision-makers (bottom-up) is questionable. Pacific Island governments are focused on economic growth, with little tangible investment in non-profit environmental sustainability. In the future they should take on ownership of the climate-change adaptation process to a greater degree than they do at present, with external assistance brought in only for special cases and for the trialling of novel solutions, rather than for routine adaptation. Globally, there should be less emphasis on sea-level rise as the principal challenge posed by climate change to Pacific Island nations and a better appreciation of the other challenges, particularly inundation and salinization of economically critical lowland, as well as coral-reef degradation.
\end{abstract}

KEY WORDS: Climate change • Pacific Islands • Environmental management • Technology • Adaptation $\cdot$ Sea-level rise

\section{INTRODUCTION}

The Pacific Islands are unique among the Earth's inhabited environments. They are located in the world's largest ocean, they are collectively large enough to have their own identity-environmental, cultural, and political-and yet small enough that they are often viewed as an unremarkable adjunct to most of the rest of the world's landmasses in global issues of climate change.

There are dangers in both underestimating the global importance of the Pacific Islands region and oversimplifying the nature of the threats posed to it by climate change. The Pacific Islands region is a sensitive indicator of projected 21st-century climate change, from the dynamics of El Niño-Southern Oscillation (ENSO) variations, the changing intensity and reach of tropical cyclones, sea-level rise, and shoreline erosion (Mimura et al. 2007, Lang \& Wang 2008, Meehl et al. 2008, Park et al. 2009). In addition, owing to the vulnerability of most Pacific islands to climate change, the responses of their governments and communities to this may presage what will become increasingly common-particularly in the developing world - over the next few decades.

The principal reason for writing the present paper is to explain the state of preparedness for future climate 
change in the Pacific Islands, as perceived by its author on the basis of $>24 \mathrm{yr}$ of intimate observation. There are other reasons, not least of which is the incomplete and often somewhat simplistic understanding of the Pacific Islands region by some concerned with global climate change and its likely impacts. There is also a desire to show a sensible way forward for Pacific Island nations and those who collaborate with them on climate-change issues.

The present paper begins with a discussion of the environmental and cultural contexts of climate change in the Pacific Islands, which is followed by an account of the climate-change challenges in the Pacific Islands, both for decision-makers within island nations and for the international community that interacts with them. A section then follows describing and evaluating the current responses to climate-change challenges, divided between technological and management responses. The next 2 sections deal with future technological and management imperatives for the Pacific Islands, highlighting both the non-sustainability of some current developmental trends and the ways in which they could be exacerbated by future climate change. The concluding section outlines recommended ways forward.

Throughout the present paper, the 'Pacific Islands' refer to the sovereign nations of the region and not to those (such as the Hawaii group) that are fully integrated parts of a developed continental nation, and can therefore access solutions to the challenges of climate change that are neither readily available nor often especially suited to the rest.

\section{ENVIRONMENTAL CONTEXT}

The diversity of Pacific Island environments confounds generalizations about the ways in which they will respond to particular aspects of climate change. The obvious distinction between higher islands and lower islands (atolls) is helpful, but also obscures many details that environmental managers need to consider (Barnett et al. 2008).

The inhabitants of high islands, like those in Fiji, Solomon Islands and Vanuatu, clearly have the potential to weather many effects of climate change in ways that countries with fewer high islands have not. Yet such observations can mislead, for almost all the people in such countries live along island coasts, routinely dependent on natural coastal systems - terrestrial and marine-for sustenance. Not only do few coastal communities own inland areas to which they could readily move, but they are also accustomed to coastal life and could not readily sustain themselves elsewhere. In many high-island nations, not only do most people live along the coast, but also most economic activity is concentrated there. Sea-level rise, therefore, has a great potential to disrupt life on high islands (Nunn 2006, Nunn \& Mimura 2006, FAO 2008).

Low (atoll) islands are inherently vulnerable to sealevel rises, and it is likely that some such islands will become uninhabitable within the next 20 to $30 \mathrm{yr}$. While manipulation of sediment movement in atoll lagoons may allow some such islands to endure longer than generally expected (Cowell \& Kench 2001, Kench \& Cowell 2001), thresholds exist within the structures of most atolls that, once surpassed, will see existing atoll islands rapidly eroded (Dickinson 1999, 2009).

People living on any type of Pacific island who interact daily with the environment to acquire food (rather than buy it) are vulnerable to the vagaries of changing climate. Increased climate variability and the impact of extreme events (e.g. droughts and tropical cyclones) will see many long-held methods of food acquisition strained, particularly as temperature rise affects crop yields and coral-reef health (Nunn \& Mimura 2006, FAO 2008). Two ecosystems are of special concern in the tropical Pacific Islands - mangroves and coral reefs. Both play vital roles in physically protecting island coasts from erosion and inundation, and both are critical in maintenance of the nearshore ecosystems on which most people living in the Pacific Islands depend.

Mangroves were common along many tropical Pacific Island coasts until 150 yr or so ago when they began to be cleared by coastal peoples, something that accelerated shoreline erosion in many places (Nunn 2000, 2003). Mangroves are a recommended part of future shoreline-protection strategies in the region and are being replanted with this in mind at a few showcase sites (Nunn 2004b, Nunn et al. 2006). It is unclear how mangroves will respond to the projected climate change over the next few decades (Gilman et al. 2006).

It is far less easy for people to manage coral-reef ecosystems than mangroves, yet coral reefs are the most enduring form of natural shoreline protection along Pacific Islands and are currently in a more degraded state than they have probably ever been (Sulu 2007). Current causes of reef degradation are mostly humanassociated, ranging from their unsustainable exploitation to their pollution. Mining and dynamiting of reefs are widespread. Coral-reef conservation is not just a 'green' issue, but should be viewed as part of a package for climate-change adaptation; a healthy reef is intrinsically better able to respond to climate change than a degraded one. Yet there is compelling evidence that coral-reef degradation has progressed to a point where its continuation, at least in the next few decades, seems unavoidable (Hoegh-Guldberg 1999b). Fig. 1 shows how changes in ocean-surface temperatures have forced bleaching episodes increasingly fre- 


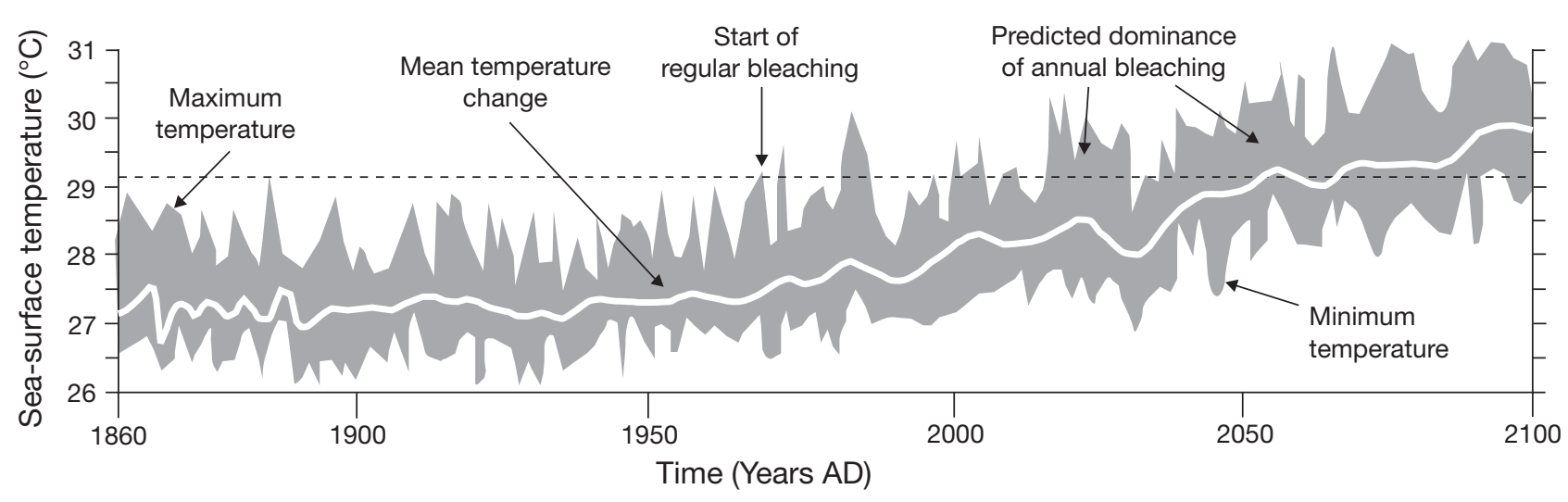

Fig. 1. Sea-surface temperatures from 1860 to 2100 AD for Tahiti, incorporating El Niño-Southern Oscillation effects, compared to the upper thermal tolerance of corals (dashed line) (after Hoegh-Guldberg 1999a). For the first 100 yr of record, sea-surface temperatures in Tahiti never rose above the coral tolerance limit, so there was no bleaching. Beginning around 1970, when mean sea-surface temperature had begun rising, temperature maxima during El Niño events reached above the coral tolerance limit and resulted in bleaching. By around 2050, it is expected that mean sea-surface temperature around Tahiti will have reached close to the upper coral tolerance threshold so that bleaching episodes will become annual occurrences

quently since the 1970s and how these episodes will become more frequent and more enduring as these temperatures continue to rise. By 2050, 'most evidence suggests that coral reefs will not be able to sustain this stress and a phase shift to algal dominated benthic communities will result' (Hoegh-Guldberg 1999a, p. 15). A more recent assessment is that bleaching will become an annual or biannual event in the next 30 to $50 \mathrm{yr}$ and that coral reefs in Micronesia and western Polynesia will be especially vulnerable (Donner et al. 2005). The effects will be widely felt, not just in physical and ecological terms, but also in societal terms, for coral-reef degradation will remove food sources that remain as important to humans as ever in the Pacific Islands (Bleakley 2004).

Outside the region, the ignorance about the geography of the Pacific Islands and the diversity of the region's terrestrial environments is legion. A widespread popular belief is that most islands are atolls and that sea-level rise is therefore the most profound problem that confronts the region (Nunn 2004b). Such ignorance clearly does not worry many climate-change players on the world stage, but it is detrimental at a regional scale (Nunn 2004a).

\section{CULTURAL CONTEXT}

To the disinterested observer, it may seem that climate change transcends culture as much as it transcends boundaries between nations. Climate change is one of the few global challenges that is forcing all the world's nations to begin to act with a common purpose. It is widely assumed that the recommended solutions to climate change can be couched in language that is universally understood, but this is not so.
In the Pacific Islands, it is often the fate of new ideas to be explained, apparently absorbed, apparently accepted, and then ignored thereafter. Climate change is widely regarded in the Pacific Islands as a foreign construct, a preoccupation of developed nations, something that has made victims of innocent Pacific Islands people, and therefore something that those responsible should and will do something about (Nunn 2004b, Nunn et al. 2006).

In the modern era, in which all Pacific Island nations are subject to the pressures associated with globalization, a culture of dependence has developed therein (Sofer 1985) that reinforces the view of climate change as an alien problem that should be solved by outsiders. That this view has apparently become established among many political leaders is proving detrimental to long-term planning (Ravuvu 1988).

It needs also to be mentioned that, while the Christianity present in every part of the Pacific Islands is undeniably a characteristic that defines the region for many people, it is also sometimes a hindrance to meeting the challenges of climate change. From outright denial of climate change to the lesser belief that Divine Providence will be a significant part of any solution to climate-change-associated problems, it is clear to the author that Christianity is used both as an excuse for inaction and as a reason for sidelining climate change in policy enforcement.

\section{CHALLENGES FROM CLIMATE CHANGE}

The challenges to Pacific Island inhabitants from future projected climate change represent processes of global forcing modulated by local environmental and cultural contexts. Yet, at the outset, those in the Pacific 
Islands should ask the questions 'What is it exactly that challenges us?' and 'What outcome do we seek to achieve?' if they are not to risk having these questions both posed and answered from outside the region by those unaware of its special circumstances (Nunn 2004a). The lack of clarity regarding the answers to such questions by Pacific Island decision-makers is one reason why there has been so little adaptive response from within island countries (P. D. Nunn unpubl.); in other words, 'there has been insufficient action to ensure that the Pacific Islands will be unaffected by climate change' (Barnett 2005, p. 216). These 2 questions are discussed in the subsections below.

\subsection{What is it exactly that challenges Pacific Island people?}

They are confronted by a series of likely climate (or climate-driven) changes that threaten the sustainability of their way of life (Nunn \& Mimura 2006, Mimura et al. 2007), largely through:

(a) increased climate variability, both the continuation of the present robust ENSO pattern that forecasts an El Niño occurring every 3 to $5 \mathrm{yr}$ and the possibility that the seasonality of annual rainfall may vary in the future;

(b) changes in climate extremes, particularly that the recent high incidence of intense tropical cyclones (hurricanes) will continue as well as the El Niñoassociated droughts;

(c) temperature rise, which will have impacts on terrestrial ecosystem productivity (particularly crop yields) and on nearshore ecosystems (particularly coral reefs) on which many Pacific Island people depend; and

(d) sea-level rise, which will inundate coasts, cause shoreline erosion and groundwater salinization of lowlying areas, and allow larger-amplitude waves to cross offshore reef barriers than at present.

Within the past $1200 \mathrm{yr}$, Pacific Island societies have proved vulnerable to various climate changes, particularly drought and sea-level fall, which have caused fundamental transformation in some societies (Nunn 2007, Nunn et al. 2007). Yet, in many cases, the increased vulnerability in the past was matched by equally high resilience, which allowed societies to recover comparatively quickly (Fig. 2). The AD 1300 event was a period of regional cooling and sea-level fall that impacted Pacific Island societies profoundly, temporarily reducing their resilience yet hardly altering their vulnerability because people adapted largely by relocation to less vulnerable locations (Nunn 2007 , Nunn et al. 2007). In recent times, major changes occurred due to the arrival of Europeans and the impo-

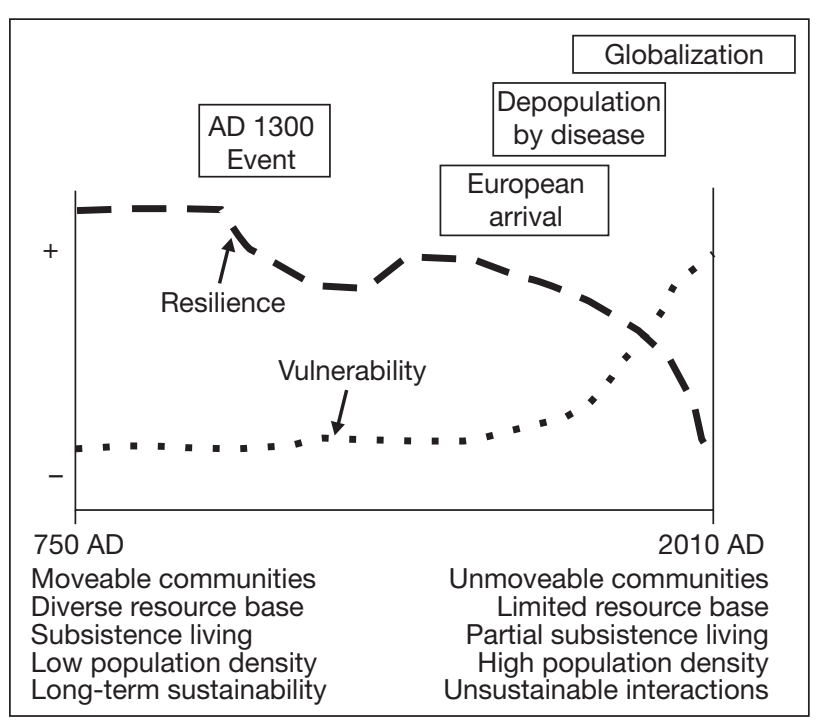

Fig. 2. Generalized view of the changing levels of resilience and vulnerability of humans to climate change in the Pacific Islands since $750 \mathrm{AD}$

sition of alien systems of human-environment interaction, followed by the depopulation of Pacific Island indigenous populations associated with the introduction of unfamiliar diseases, and, more recently, the processes of globalization, particularly the establishment of networks of dependency within and beyond the region (McNeill 1994, 1999).

The difference today is that Pacific Island societies have become completely sedentary in ways that they were not even $200 \mathrm{yr}$ ago. In common with most other parts of the inhabited world they have become part of the 'global family', an increasingly homogenous society of which its tangible building blocks (for example, buildings, infrastructure, farms, fishing grounds) have become fixed (not transitory or mobile) and in which its intangible qualities (like financial investment, income generation, education) have become inexorably tied to these fixed elements. What challenges today's Pacific Island societies is, therefore, the future disruption of these developmental trajectories.

\subsection{What outcome do Pacific Island people seek to achieve?}

Many politicians in the Pacific Islands are concerned that nothing should disrupt progress and development (for in this lies the best chance of re-election). Most educated, non-partisan people in the Pacific Islands appear to feel otherwise, noting the widespread environmental cost of such progress, from the cavalier disposal of toxic mine waste (Brown 1974, Hettler et al. 
1997) to deforestation (Hviding \& Bayliss-Smith 2000, Lomo 2001), and wish for truly sustainable development. Many less formally educated people, particularly in rural areas, are typically less concerned about their islands' long-term future and more concerned about fulfilling their short-term needs (Thistlewaite \& Davis 1996, Nunn 2004a).

So maybe the question should be rephrased to: 'What is best for the Pacific Islands to ensure that their environments will continue to sustain their inhabitants in the future'? Maybe no-one from outside the region should presume to ask such a bold question, but if it is not answered properly soon and the answer acted upon effectively, many of the bleak prognoses for Pacific Island environmental futures may prove correct (Zurick 1995, Nunn et al. 1999, Pelling \& Uitto 2001, Nunn 2004a, 2006, 2009).

In terms of what is needed to effectively confront the challenges of projected climate change in the Pacific Islands, it is helpful to separate the needs of in-country (national) decision-makers and intra-regional advisory bodies from the needs of extra-regional (international) decision-makers.

\subsection{Challenges for in-country decision-makers}

An important challenge for national decision-makers in Pacific Island countries is to understand the challenges posed by climate change to the extent that their responses can be significantly informed by both the science of climate change and its likely impacts within the country in question. It is simplest to identify 3 levels of in-country decision-making in the Pacific Islands - governmental decision-making, communitybased decision-making, and decision-making by nongovernmental organizations.

For governmental decision-making, one of the first issues that stands out is the comparatively small number of trained people qualified to influence national climate-change policy (Nunn et al. 2006). Most of these people are university graduates, $<40$ yr old, who, upon joining governments quickly realize the near-impossibility of actually influencing policy. In such democratic developing countries of typically $<1$ million citizens, few politicians are brave enough to follow through with policies that will hinder economic development. Most citizens want their income increased between elections, and not all politicians will find jobs outside parliament that pay as well as within, so, although there have been many bold statements about sustainable development made by Pacific Island leaders (e.g. Pacific Plan 2007), the underlying reality is that sustainable development is not a real policy goal of any Pacific Island government.
Many efforts have focused on building capacity within governments to understand and confront the challenges of climate change. Most of these efforts have failed in the sense that no Pacific Island government has developed a country-specific climate-change action plan significantly at variance with international agendas. International priorities have uncritically become national priorities. The clearest manifestation of this is in the policy arena, with most Pacific Island nations having an impressive body of environmental legislation pertinent to climate change, but no will and no way to enforce it (Turnbull 2004).

The impotence of national policy in effecting appropriate decision-making in Pacific Island nations means that decisions about particular environments are generally taken by the leaders of the people occupying these environments. Community-level decision-makers are generally more concerned with sustainable interactions between people and the environment, even to the point of sometimes resisting proposals for development that may entail a loss of sustainability (Kuijper 2003, Hviding 2006). Yet community-level decisionmakers are often less well educated in the science of climate change and the nature of appropriate responses. The challenge is therefore to find ways to empower such people to make appropriate decisions.

Finally, there is a role for non-government organizations (NGOs). There is considerable diversity in the nature, membership, and mandates of such NGOs in this region. International NGOs like Greenpeace and the World Wide Fund for Nature (WWF) pursue largely international agendas, which may be important in a global context, but sometimes make little sense in a community context. For example, many NGOs place a huge emphasis on biodiversity conservation, often to the point of underrating the daily needs of locally dependent communities. Many regional and national NGOs have picked up on parts of these agendas, but typically also merge these with priorities identified in-country. Some NGOs, particularly those linked to particular religions, have considerable unrealized potential to influence environmental decision-making (Takesy 2004).

The fostering of improved understanding of the nature of climate change (and of potential related solutions) and enforcement (implementation) of climaterelated policy are the 2 greatest challenges for incountry decision-makers in the Pacific Islands. There is a comprehensive lack of understanding about climate change amongst most influential government decisionmakers who typically allow action on climate change to be subordinated to decisions that will lead to shortterm economic growth. There is hardly any effective enforcement of legislation concerned with climatechange adaptation and mitigation. 


\subsection{Challenges for intra-regional advisory bodies}

The comparative small size of Pacific Island countries and their economies combined with the commonalities of the challenges they face in a number of areas (not just from climate change) make it understandable that these countries have developed regional approaches to many of these threats. These regional approaches are served through a number of organizations whose mandates are set by representatives of member countries, and, since none of these are developed countries, it is understandable that these mandates are preoccupied with economic development. Two of these organizations (SPREP and SOPAC) have climate change as one of their specialist areas.

SPREP (South Pacific Regional Environment Programme) is the appointed interface between most Pacific Island nations and the international climatechange community, representing island nations' views in particular fora, applying international agendas to the context of the Pacific Islands, and advising Pacific Island governments on priority areas for combating climate change. Among the latter are improvement of meteorological services, enhanced awareness of climate change throughout the region, policy development, and action on ozone-depleting substances.

For a long time implacably opposed to the idea that temperatures and sea level were rising and would rise further during this century, SOPAC (South Pacific Applied Geoscience Commission) has changed its stance within the last $10 \mathrm{yr}$, now advising island governments of the direct opposite of what they advised them previously. The role of SOPAC in climate-change studies in the Pacific Islands was formerly to gather and process environmental data that demonstrated the facts of climate change, but this role has now been extended into awareness raising and appropriate policy formulation.

The role of intra-regional advisory bodies is determined by their member countries, but it could be argued that this role should extend to advising member countries about the non-sustainability of the paths currently being pursued by governments with respect to the environments of the Pacific Island countries, particularly with reference to their exploitation for shortterm economic gain. To date, the writer is not aware of any of these bodies having made such a statement in unequivocal terms.

\subsection{Challenges for the international community}

The international community needs to effectively communicate the challenges of climate change to Pacific Island decision-makers. For most Pacific Island people, English is at least a second language and not the one that most are comfortable speaking, reading, or listening to at length. Yet there is a widespread expectation among the international community that, because English is the one common language of Pacific Island nations, it should be possible to use English to effectively communicate even high-level science to high-level decision-makers (in government, for example), as well as to convey apparently simple ideas to moderately well-educated people (at the community level, for example).

None of these expectations is valid, not because Pacific Island people are unintelligent, and not because they lack interest or commitment in confronting the challenges posed by climate change, but, in many cases, because of language and cross-cultural problems that inhibit communication. Climate-change issues are viewed quite differently across cultures; one of the most extreme examples may be the competitions for the best climate-change jokes that have been sponsored at some US-based meetings (which the writer attended), something that may be considered appropriate in the cocooned environments of Washington, DC, but is repellent to vulnerable people in the Pacific Islands.

So the challenge for the international community outside the Pacific Islands is not simply to communicate in the way that they are accustomed to doing with each other, but to communicate in ways that will ensure their message is clearly apprehended by those for whom it is intended. Anything less is largely a waste of time and resources.

Cross-cultural problems associated with communication about climate change between the international community and Pacific Island peoples also extend to conceptualization (Hviding 2003, Wood 2003). Science may be taught in much the same manner everywhere in the world, but the language used around the interface of science and society is often more obscure and region-specific. For example, to explain adaptation to climate change by talking of specific concepts, such as anticipatory adaptation and no-regrets adaptation, may often make these concepts appear to be alien to Pacific Islanders, whereas, in fact, they have been doing all these things for decades, even centuries. For people who interact daily with the natural environment, the dialectics of modern climate-change science may simply obscure familiar ideas and responses. The best way to effect changes in people's attitudes and responses in such situations is to cut through the language and conceptual barriers and explain things in familiar terms in a familiar language using familiar examples.

Finally, problematic is the use of strategies, such as for climate-change adaptation, that have been tried 
and successfully tested elsewhere in the world and that are imposed unthinkingly on the environments of smaller islands where such strategies may be inappropriate (Nunn 2004a,b). Hard-fix solutions to problems of shoreline erosion are appropriate for richer countries having comparatively short coastlines along which there has been concentrated investment (private and public). There is a glaring need to protect this investment, and the money is generally found to do so in the most appropriate way. Given the degree to which humans have often already interfered with such coasts, the usual solution is to construct artificial structures, the design of which has been decided by modelling coastal dynamics. But poorer countries, such as those in the Pacific Islands, where perhaps the entirety can be classified as coastal, cannot entertain such solutions. Firstly, there are insufficient data available to enable a sufficient understanding of coastal dynamics to know what structures are most appropriate. Secondly, such structures are prohibitively expensive to construct, although aid funding is one possible way in which this can be done. Finally, the cost of maintaining such structures is often beyond the means of such countries, so they often fall into disrepair and their original function is thereby negated.

An attendant problem with the display of hard-fix solutions, often aid-funded, in showcase locations in the Pacific Islands, typically in the centres of capital cities, is the spread of what has been called the 'seawall mindset' (Nunn 2004b). This refers to the uninformed emulation of such solutions by rural communities, which, anxious about their eroding shorelines and unable to access sound advice about sustainable solutions, simply build vertical impermeable seawalls because this is what appears to work in the showcase locations (Fig. 3a). These rural seawalls are typically opened with great fanfare but collapse 12 to 18 mo later as a result of scour along their fronts and ponding along their backs. Seawalls may be repaired or rebuilt if funds are available, but many of the communities that they enclose are only partly within the cash economy, and the common result is that such seawalls remain in a state of collapse (Fig. 3b).

In the Pacific Islands region, little thought seems to have been given by the international community about how their messages about climate change are received and permeated throughout the region. These mes- sages are manifestly not bringing about the desired results because of problems associated with language, communication, with conceptualization, and with the dissemination of climate-change understanding.

\section{CURRENT RESPONSES TO CLIMATE-CHANGE CHALLENGES}

In countries of the developing world such as those of the Pacific Islands, governments often have very little money to invest in things that will not yield a shortterm financial gain. Funds are therefore ploughed into
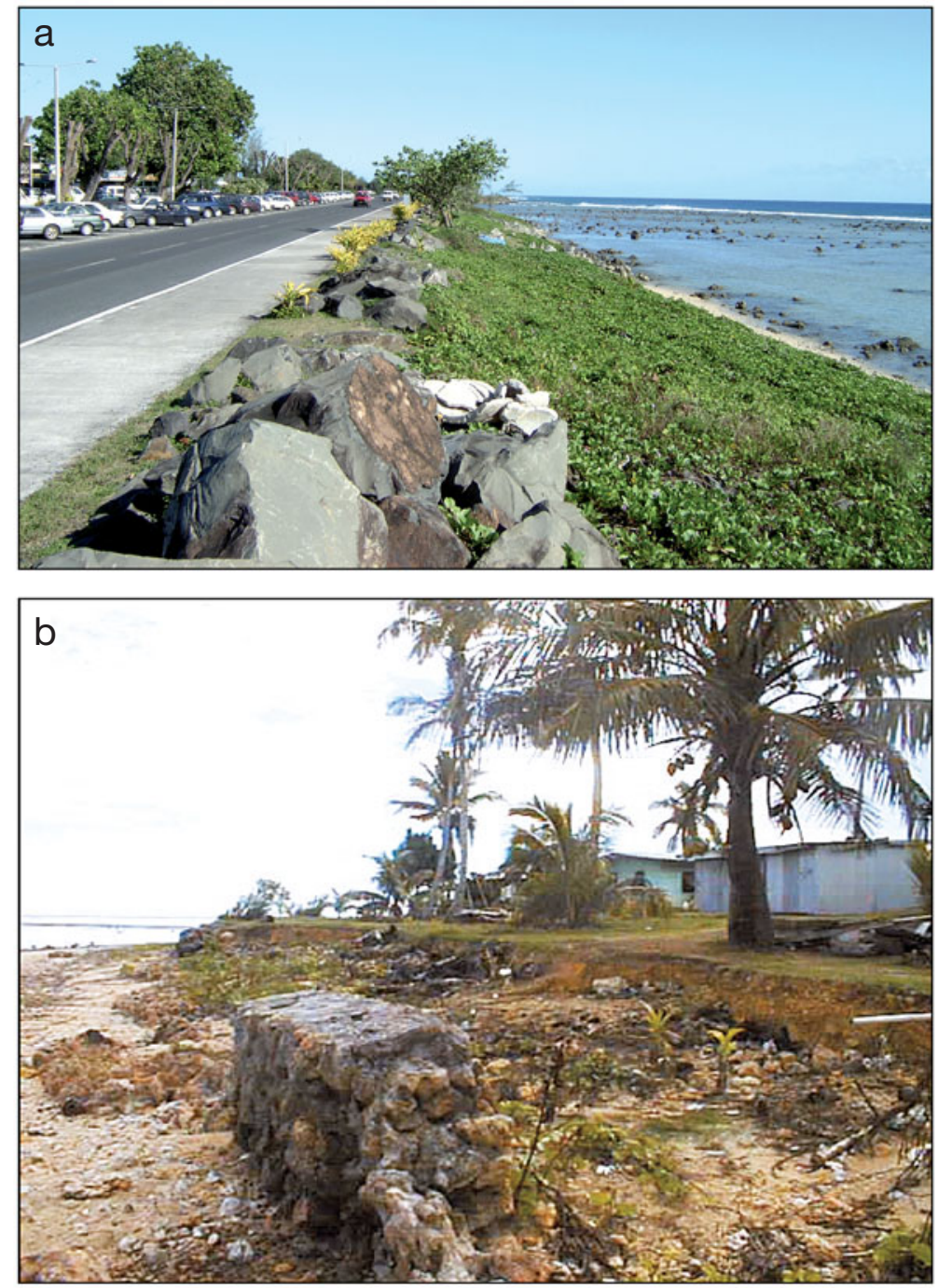

Fig. 3. Artificial structures along Pacific Island coasts. (a) Aid-funded artificial shoreline along the front of Avarua, the capital city of the Cook Islands. Large boulders have been piled up along the shoreline, covered by mesh in places, and vegetated. (b) Remains of a typical rural seawall in the Pacific Islands, at Yadua Village, Viti Levu Island, Fiji. The original seawall remained intact for $18 \mathrm{mo}$, was partially rebuilt, then collapsed again. Note how wave scour has begun eroding the area behind the original seawall, cutting into the coastal plain and threatening the nearby houses 
tourism, mining, and forestry, while issues such as environmental conservation and ecosystem sustainability are marginalized, generally receiving enough funding only to satisfy international watchdogs. Often that funding comes solely from external sources, governments understanding that subscribing to the rhetoric of sustainable development and ratifying all the relevant international agreements will ensure a steady flow of external assistance. There have been many instances where such assistance, earmarked for sustainable development, has been diverted into other areas, particularly those supporting revenue generation (Turnbull 2004, Huffer 2005, Barclay \& Cartwright 2007).

In consequence, the responses of most Pacific Island countries to climate-change challenges have been less than satisfactory to date, in terms of both the types of responses (technological and management) and the evenness of their distribution within countries. The latter point is so important and so under-acknowledged that it is worth developing briefly.

All nations have a core (or cores) in which most development is concentrated and a periphery where development tends to be less. Other core-periphery contrasts that are apparent in most countries are differences in the ways of life, the cores usually being at the forefront of progress, the peripheries tending to be more traditional. Contrasts between the core(s) and the periphery in most Pacific Island countries are amplified by their archipelagic nature. Most of the peripheries in continental countries are accessible by road, but in archipelagic countries they are far more difficult to access. Young adults have left outer-island (peripheral) communities in many parts of the Pacific Islands in search of waged employment so that traditional lifestyles are reinforced on the periphery by interactions between elderly people and young children.

The environmental and cultural disparities between cores and peripheries in most Pacific Island countries also affect the ways in which climate-change solutions are understood and implemented (Kumar 2007). In core areas, there is generally better understanding and more appropriate solutions are adopted. In the often vast peripheries, hardly ever visited by government environmental officers or representatives of international climate-change agencies, there is widespread misinformation about climate change, and environmental decision-making is conditioned largely by instinctive responses (P. D. Nunn unpubl.).

This section describes and evaluates the existing (and recently tried) responses to climate change in the Pacific Islands, separating technological from management responses (Table 1). The section focuses on adaptation responses rather than on mitigation responses, the latter being largely the same throughout the Pacific Islands region.
Table 1. Recent and current adaptation responses to climate change in the Pacific Islands

\begin{tabular}{|c|c|}
\hline Change & Response \\
\hline \multicolumn{2}{|c|}{ Technological responses } \\
\hline $\begin{array}{l}\text { Increased climate } \\
\text { variability }\end{array}$ & $\begin{array}{l}\text { Negligible. Improvements of water } \\
\text { management practices are in response } \\
\text { to unsatisfactory water management } \\
\text { under current conditions }\end{array}$ \\
\hline Climate extremes & $\begin{array}{l}\text { Piecemeal, uncoordinated, often un- } \\
\text { informed }\end{array}$ \\
\hline Temperature rise & Piecemeal \\
\hline Sea-level rise & $\begin{array}{l}\text { Some. Construction of artificial struc- } \\
\text { tures, ranging from showcase struc- } \\
\text { tures in city centres to poorly planned } \\
\text { seawalls in peripheral areas }\end{array}$ \\
\hline \multicolumn{2}{|c|}{ Management responses } \\
\hline $\begin{array}{l}\text { Increased climate } \\
\text { variability }\end{array}$ & $\begin{array}{l}\text { Negligible. Extra-regional predictions } \\
\text { of forthcoming El Niño events are not } \\
\text { acted upon }\end{array}$ \\
\hline Climate extremes & $\begin{array}{l}\text { Some. Upgrading of meteorological } \\
\text { services for improved weather predic- } \\
\text { tion, especially early warning of } \\
\text { tropical cyclones, is a response to the } \\
\text { perceived climate of recent years. } \\
\text { Disaster-management strategies are } \\
\text { largely reactive and not proactive. } \\
\text { Community-based response plans to } \\
\text { disasters have been developed after } \\
\text { particular events }\end{array}$ \\
\hline Temperature rise & $\begin{array}{l}\text { Little. Trialling of new crop strains, but } \\
\text { most of this is in response to demands } \\
\text { for increased production }\end{array}$ \\
\hline Sea-level rise & $\begin{array}{l}\text { Some. Government and aid schemes to } \\
\text { protect key (or pilot) areas. Govern- } \\
\text { ments have received reports on likely } \\
\text { effects of future climate change. Some } \\
\text { new infrastructure being built inland of } \\
\text { vulnerable areas }\end{array}$ \\
\hline
\end{tabular}

\subsection{Technological responses}

In the past, appropriate human responses to climate change in the Pacific Islands were simpler to implement than they are today (Mimura \& Nunn 1998). People moved from vulnerable to less vulnerable areas. The disruption was relatively slight because communities were not sedentary to the degree that they are today. Comparative ease of movement was helped by the absence of any formal system of land ownership (such as exists today), by low population densities on particular islands, and almost certainly by the memory of communities having moved in the past for similar reasons. The latter point should not be underestimated. Today the idea of relocation of settlements is anathema to most people and communities in the Pacific Islands region.

A good example comes from the societal crisis around $1300 \mathrm{AD}$ in the tropical Pacific Islands (see Fig. 2) that was driven by climate change, principally cooling (Nunn 2007, Nunn et al. 2007). Climate change 
led to a sea-level fall, which caused an enduring food crisis along many island coasts. People responded by abandoning coastal settlements in every part of the tropical Pacific Islands region (from the Solomon Islands in the west to French Polynesia in the east) in favour of inland hilltop settlements where they would be safer from the associated conflict.

Understandably there is far more resistance to relocation as an adaptation option in the modern Pacific Islands region, but the essential vulnerability of island environments that led to wholesale population relocation during the 'AD 1300 event' has not changed. Part of the reason for this is that there are no obvious, widely available technological fixes to the challenges of climate change in this part of the world. Coastlines are extraordinarily lengthy in the Pacific Islands compared to total land areas, and most Pacific Island nations are comparatively poor and therefore doubly handicapped when it comes to technological fixes to the challenges of climate change.

Some work has focused on traditional coastal protection in the Pacific Islands, work that has been driven by the broader agenda that traditional solutions to environmental problems are the key to sustainable human-environment interactions in such societies (Johnson 1992, Morrison et al. 1994). Yet it seems that human memories concerned with shoreline protection in the Pacific Islands, which might be expected to have 200 to 300 yr recollection spans, consistently fail to report anything that could be helpful in the modern context. Relocation was evidently the preferred adaptation option until the 20th century in most parts of the Pacific Islands (Mimura \& Nunn 1998).

Archaeological investigations in parts of the Pacific Islands suggest that, in especially vulnerable locations, climate change led to significant human modifications of refuge environments. For example, on the remote Kapingamarangi Atoll in the Federated States of Micronesia, there is evidence that a natural sand accumulation was manipulated by people around $1400 \mathrm{AD}$ to make it habitable, it eventually becoming Touhou Islet. Equivalent evidence for the extension of the lowland area of Lelu Island in Kosrae (Federated States of Micronesia) is suggested by its increased occupation about 1400 AD. Artificial islands in many parts of Pacific Island countries may have been constructed in response to the need for refuges from conflict arising from climate-driven resource depletion (Nunn 2007).

\subsection{Management responses}

Most Pacific Island governments have units of government responsible for national environmental management. Within a few, there may be a person with special responsibility for climate change. Typically that person (like others within the unit) will be on a shortterm contract funded by external aid/project funds (Barnett 2005).

Many more people in Pacific Island governments may have attended courses intended to build their government's capacity to deal with the challenges of climate change. By and large, most of these people are ineffective in bringing about changes in government policies concerning climate change, even to the extent of working in areas of government with hardly any involvement with climate-change activities.

To understand the ineffectiveness of the responses of many Pacific Island governments to the challenges of climate change, it is also necessary to focus on the comparative small size and poverty of these countries.

Smallness means small numbers of government employees, and few in areas like environment that are not self-funding. Many of the government employees in the Pacific Islands charged with environmental management are so overstretched (and attend so many international meetings) that they are simply unable to develop or effectively implement appropriate strategies for climate change.

Then there is the issue of poverty, which means that, while government income may be used to showcase the nation globally, it is rarely used for anything else that does not generate revenue. Thus, skyscrapers cluster along the ocean fronts of many Pacific Island cities, while governments invest heavily in infrastructure that services economic activities. Funding for nonrevenue-generating activities like natural-disaster prevention, individual poverty alleviation (inequality of wealth distribution), and cultural-heritage preservation, is commonly from non-government, non-recurrent sources.

Many international aid donors to the Pacific Island countries accept this situation, actively sustaining it by targeted programs that include many aspects of climate change adaptation and mitigation. This situation is continuing to encourage the subordination of climate change (and environmental issues more generally) by Pacific Island governments: a case study of Niue was presented by Barnett (2008). It is sending a message to these governments to continue their preoccupation with revenue-generating activities because aid will always be on hand to cope with many of their other responsibilities.

Compounding this situation is the emphasis placed by many international aid donors to Pacific Island countries on policy development. Millions of dollars have been poured into policies for sustainable development in the Pacific Islands, but in none of the recipient nations is there effective enforcement of these policies. To international donors, policy development is an 
attractive area for funding support because it is clearly an act of nations supporting nations, in a bilateral sense. Yet few donors have paused to ask how effective this is in the Pacific Islands. For, while a few selected communities have benefited for a few years from being the objects of pilot studies, there has been no widespread improvement in knowledge about climate change or responses to its many manifestations in any of the Pacific Island countries as a result of policy development (P. D. Nunn unpubl.).

\subsection{Understanding processes of environmental decision-making}

In this section, the emphasis will be on the important ways in which the processes of environmental decision-making differ from those in many other countries. The challenges of sustaining appropriate adaptation are also discussed.

In most parts of most Pacific Island nations, decisions about the environment are made by the community that owns the area in question. A coastal community that experiences shoreline erosion will generally discuss and decide what to do about it. The hierarchical nature of most Pacific Island communities means that the experiences of the acknowledged leaders of these communities dictate what will happen. And those experiences are most likely to be informed by traditional human-environment interactions, often quite different to what is happening today, and not informed by scientific understanding of either the local environment or the wider context of climate change (P. D. Nunn unpubl.).

Government policy or even government-sponsored advice rarely plays any role in local-area community decision-making of this kind. This is largely because of the lack of enforcement of policies, the lack of sufficient dissemination of relevant policies and advice, and, conversely, the determination of local communities to have the final say (and resist outside interference) in decisions concerning their land. It is this kind of situation that ensures that top-down solutions do not work well in the area of environmental governance in the Pacific Islands (P. D. Nunn unpubl.).

These processes are amplified in archipelagic countries (like many Pacific Island nations), where development gradients between cores and periphery are steeper than in countries of no or few islands. Work on this issue in Fiji highlighted the situation on Moturiki, an island within the development periphery (Kumar 2007). Most coastal communities on the densely populated island of Moturiki made a series of what appeared at the time to be appropriate decisions, but which generally proved calamitous. Most common among these was the construction of seawalls, which because of their design generally exacerbated the problems of shoreline erosion they were intended to solve. Many communities on the island also removed the previously cleared mangrove fringe as soon as it showed signs of regrowth, thereby prolonging the heightened vulnerability arising from clearance (Nunn 2000).

Most people in the Pacific Islands are religious and are guided in many aspects of life by church leaders. Such people also have inputs into environmental decision-making, but these typically tend to emphasize the power of piety and prayer rather than other solutions. This is not to devalue the sincere effort by many churches in the Pacific Islands to understand climate change, but there is a problem with disseminating that understanding top-down (Takesy 2004).

Finally, in understanding environmental decisionmaking in most parts of the Pacific Islands, it is important to acknowledge the inputs of people within the community perceived as learned, but whose learning may be inappropriate to the situation at hand. Schoolteachers' opinions are often solicited in this context, even though their training has not necessarily given them the answers required. Yet, in the cultural context of the Pacific Islands, it is generally inappropriate to refuse outright to give advice when asked even though you may know you may not be qualified to give it.

\subsection{Implementing and sustaining appropriate adaptation}

There is a challenge in identifying appropriate adaptation to climate change in the Pacific Islands. It is also important to understand how the cultural context affects both the implementation of appropriate adaptation and its sustainability.

Any kind of top-down solution is likely to fail in the Pacific Islands context, not just because of the ineffectiveness of the associated pathways of knowledge transfer, but also owing to resistance from landowning communities to anything that could be construed as interfering with their right to manage their own land. For such reasons, it is considered that the most effective way for outsiders to inform environmental decision-making in the Pacific Islands is by having a direct input at a community level (bottom-up rather than top-down). Pacific Island governments are naturally ambivalent towards such a strategy, seeing it, on the one hand, as an admission of the ineffectiveness of their preferred top-down approaches, and, on the other hand, acknowledging its efficacy.

Governments are best placed within the Pacific Islands to undertake such programs of community out- 
reach, but few do systematically, at least in the field of environmental decision-making. To date, the NGOs have been most effective in advising communities on how to best respond to the challenges of environmental management, including climate change. Some of the best examples are found in forestry, where NGOs, which do not profit from logging, are often able to advise communities of their choices before they allow their forests to be logged (Hviding \& Bayliss-Smith 2000). Another example comes from mangrove replanting as a solution to shoreline erosion; NGO personnel are able to invest more time in advising on sustainable solutions than governments, which tend to favor short-term, hard-fix solutions like seawalls (Mimura \& Nunn 1998).

NGOs are perceived differently from governments by local-area communities; they are often able to spend more time engaging the community and often bring in volunteers for prolonged attachments, thereby displaying the kind of commitment that governments cannot afford. Further, NGOs often come with some funding attached, which is a powerful incentive for communities to listen to their message and act on it. Finally, NGOs often exhibit the kind of long-term interest in projects within particular communities that governments are generally unable to do.

In this analysis, it seems better for appropriate climate-change adaptation strategies to be directed to local communities in the Pacific Islands through NGOs, but, as seen above, they all have different agendas, even on the issue of climate change, which may not prove to be helpful in the long term. One reason for this is that there are simply too many communities troubled by climate-change linked problems in the Pacific Islands for each one to be visited individually; thus, strategies need to be developed whereby the experiences of one community can be shared with similar communities. The Internet is an obvious tool for sharing experiences in the future, but, for now, given that most rural communities have no Internet access, more practical ways of sharing experiences need to be developed.

Sharing experiences is also a way of helping ensure that appropriate adaptation solutions are sustained in the Pacific Islands. The problem of sustainability, so alien to people in developed countries (who expect their governments to do it), is profound in the Pacific Islands, especially when the solutions to be sustained are dependent on external factors, as well as on continued management inputs by the local community. The point can be illustrated as follows.

In Japan or the coastal USA, artificial shoreline protection structures are commonly designed to be appropriate for particular coasts, they are built with government (or state) funds, and, should they collapse or fall into disrepair, the same sources of funding are available for their prompt restoration. Thus, the artificial adaptation solution is sustained. The role of the local community is often confined to drawing the government's attention to the needs of adaptation.

In the Pacific Islands, an environmental management strategy involving an artificial shoreline structure may be built with locally raised funds, perhaps with some support (money or material) from the government. But should the structure need repair, the costs of that would generally be borne entirely by the local community. Many local communities are only partly within the cash economy and find fund-raising difficult, especially for maintenance costs, so eventually such structures may be abandoned (see Fig. 3b).

\section{TECHNOLOGICAL IMPERATIVES}

There is no doubt that Pacific Island nations need appropriate technological solutions for adaptation to climate change-present and projected. To date, unless aid-funded and constructed, technological solutions have largely been uninformed emulations of solutions employed in metropolitan countries (to which they may be well suited), but which do not provide sustainable solutions in most parts of the Pacific Islands.

In the Pacific Island context, appropriate solutions would not only be ones that are part of a package of adaptation to future climate change, but are also those that acknowledge the special character of island nations per se, as well as those of the environments and cultures of the Pacific Islands. The key climatechange issues in the region that require technological solutions, both in the present and the future, are summarized in Table 2.

In Table 2, it can be seen that the key (not all) effects of increased climate variability will be in the agricultural and water supply sectors. The associated technological imperatives involve conserving and more efficiently managing existing resources, besides looking into how to reduce these sectors' exposure to climate change by changing crop types and improving food preservation and water-storage capacity.

Changes in the frequency and magnitude of climate extremes are also likely to affect the agriculture and water sectors. In addition, an increased tropicalcyclone frequency and intensity is likely to have an increased impact on the built environment of Pacific Island nations (Table 2). The most effective way to reduce the exposure of vulnerable units is to relocate them to places where less exposure is likely. Exposure can also be reduced by changing the nature of the unit so as to make it less vulnerable to climate extremes; for example, some crops are better able to withstand 
Table 2. Technological and management imperatives for adaptation to key climate-change issues in the Pacific Islands region

\begin{tabular}{|c|c|c|c|}
\hline Change & Problem & Technological imperatives & Management imperatives \\
\hline \multirow[t]{2}{*}{$\begin{array}{l}\text { Increased climate } \\
\text { variability }\end{array}$} & $\begin{array}{l}\text { Variable agricultural } \\
\text { productivity }\end{array}$ & $\begin{array}{l}\text { Reduction of vulnerability by } \\
\text { soil/water conservation, } \\
\text { changed crop types/strains, } \\
\text { improved food preservation }\end{array}$ & Long-term planning \\
\hline & Variable water supply & Improved storage capacity & Improved water management \\
\hline \multicolumn{4}{|c|}{ More climate extremes } \\
\hline \multirow[t]{2}{*}{ Tropical cyclones } & $\begin{array}{l}\text { Increased infrastructure/ } \\
\text { building damage }\end{array}$ & $\begin{array}{l}\text { Relocation of exposed units; } \\
\text { improved design/materials for } \\
\text { new units }\end{array}$ & $\begin{array}{l}\text { Hazard mapping; enforced } \\
\text { zoning, building laws }\end{array}$ \\
\hline & $\begin{array}{l}\text { Increased damage to } \\
\text { subsistence food sources }\end{array}$ & $\begin{array}{l}\text { Relocation of exposed sources; } \\
\text { use of less vulnerable locations; } \\
\text { use of less vulnerable food } \\
\text { sources }\end{array}$ & $\begin{array}{l}\text { Subsistence food supply } \\
\text { mapping and planning }\end{array}$ \\
\hline \multirow[t]{2}{*}{ Drought } & Decreased/variable food supply & $\begin{array}{l}\text { Changed crop types/strains; } \\
\text { improved food preservation; }\end{array}$ & $\begin{array}{l}\text { Appropriate contingency } \\
\text { planning techniques for agri- } \\
\text { cultural water-conservation }\end{array}$ \\
\hline & Decreased water supply & Improved storage capacity & \\
\hline \multirow[t]{2}{*}{ Temperature rise } & $\begin{array}{l}\text { Decreased productivity of } \\
\text { key crops }\end{array}$ & Research into new crops/strains & Sponsorship of research \\
\hline & Increasing coral-reef bleaching & $\begin{array}{l}\text { Conservation/restoration of } \\
\text { coral reefs }\end{array}$ & $\begin{array}{l}\text { Enforce appropriate } \\
\text { legislation; declare marine } \\
\text { protected areas }\end{array}$ \\
\hline \multirow[t]{4}{*}{ Sea-level rise } & Coastal inundation & $\begin{array}{l}\text { Relocate vulnerable people } \\
\text { and units }\end{array}$ & $\begin{array}{l}\text { National strategy plans } \\
\text { required }\end{array}$ \\
\hline & $\begin{array}{l}\text { Shoreline erosion (and } \\
\text { consequent nearshore } \\
\text { sediment mobilization) }\end{array}$ & $\begin{array}{l}\text { Appropriate artificial structures; } \\
\text { mangrove reafforestation; } \\
\text { coral-reef conservation }\end{array}$ & Appropriate advice needed \\
\hline & $\begin{array}{l}\text { Groundwater salinization in } \\
\text { coastal lowlands }\end{array}$ & Relocate affected agriculture & $\begin{array}{l}\text { National strategy plans } \\
\text { required }\end{array}$ \\
\hline & $\begin{array}{l}\text { Larger waves able to cross } \\
\text { reefs and reach island } \\
\text { shorelines }\end{array}$ & $\begin{array}{l}\text { Relocate vulnerable people } \\
\text { and units; conserve/restore } \\
\text { coral reefs }\end{array}$ & $\begin{array}{l}\text { National strategy plans } \\
\text { required }\end{array}$ \\
\hline
\end{tabular}

droughts and strong winds than others. Agricultural techniques that maximize the use of the available water should be encouraged. In this context, the revival of traditional knowledge concerning waterconservation techniques and food preservation should be encouraged.

Temperature rise is also likely to impact the agricultural sector (Table 2), but not nearly as much as mean annual precipitation changes for which there are still no reliable projections for the Pacific Islands for the rest of this century. Research into crops and crop strains that are more tolerant of higher temperatures is recommended. The issue of coral-reef bleaching and degradation and its impact on coral-reef ecosystem productivity is one for which there is no readily apparent technological solution. Certainly the conservation of existing reefs and, where appropriate, the restoration of degraded reefs is encouraged.
Along many Pacific Island coasts, sea-level rise is already an issue, and one that it is projected to become even weightier in the future. There are 4 major effects of sea-level rise that are relevant to Pacific Island coasts (Table 2).

(1) Coastal inundation (permanent flooding of coastal lowlands) can be sustainably solved in most parts of the Pacific Islands only by relocation of the affected people, agriculture, and built environment (Fig. 4a). Expensive technological fixes are likely to provide only a temporary solution.

(2) Shoreline erosion can be countered by the construction of appropriate artificial structures, but these are commonly expensive to both build and maintain and often have unanticipated deleterious effects on the environment (Fig. 4b). It is better to implement natural solutions, such as the planting of mangrove forest and/or the restoration of coral reefs. 

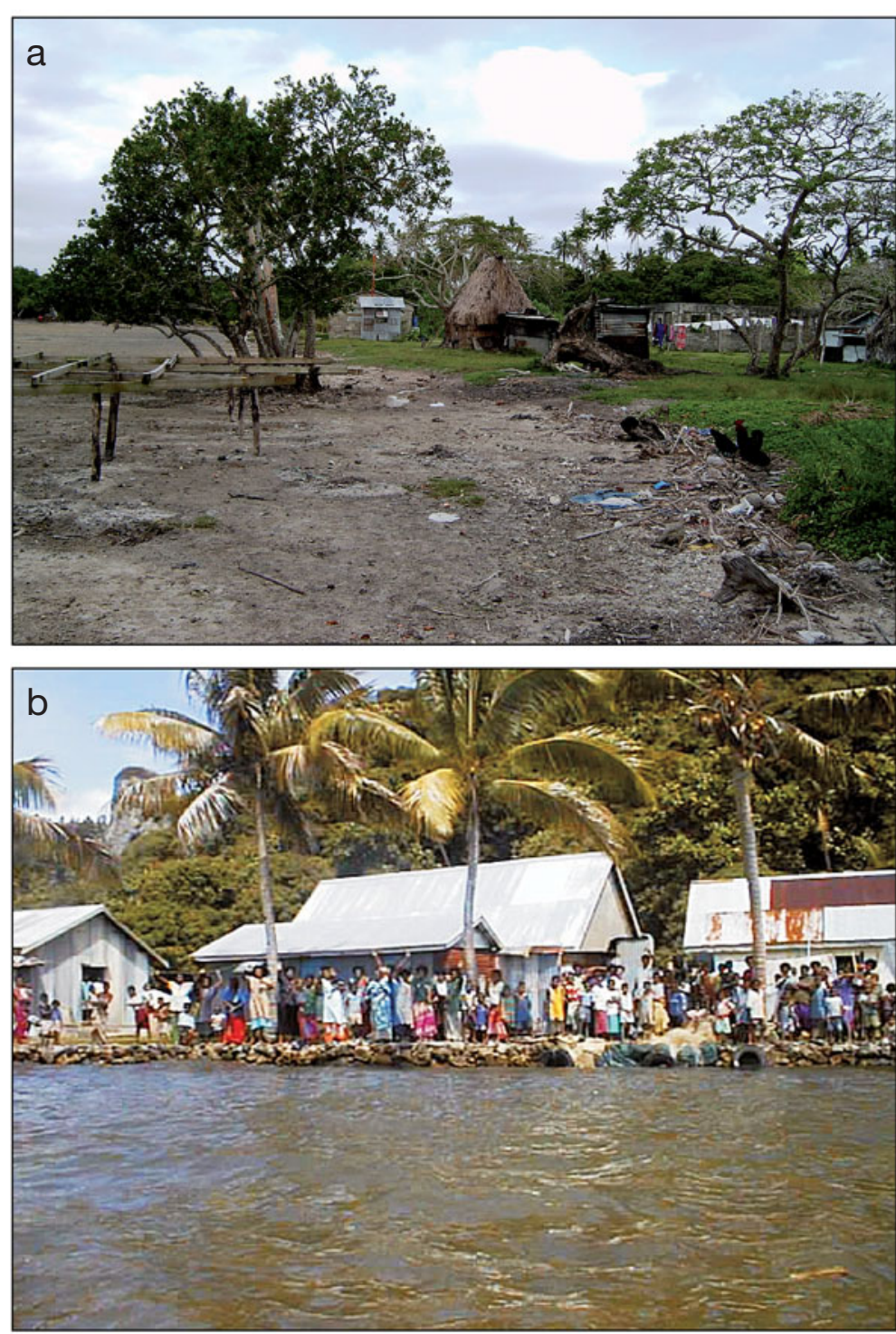

Fig. 4. Views of coastal settlements on Moturiki Island, Fiji, part of this nation's developmental periphery. (a) Low tide at Naicabecabe Village. The mean high-water mark can be clearly seen. During high spring tides, the village is underwater. (b) The people of Navuti Village stand on their seawall at high tide. The seawall suffered from scour along its front, and altered the nearshore ecosystem in unanticipated and undesired ways. A $10 \mathrm{~cm}$ sea level rise will see Navuti permanently inundated

(3) Groundwater salinization in coastal lowlands cannot be effectively reversed for affected agriculture. The only viable solution in the Pacific Islands context is its relocation.

(4) A sea-level rise will also allow larger-amplitude waves to cross protective offshore reef barriers and reach island shorelines where they may have an unprecedented erosive effect. Conserving coral reefs so that they are optimally able to respond to a sea-level rise is helpful, but the only long-term solution is relocation.
There are many possible technological solutions to the issues associated with sealevel rise described above (and listed in Table 2), and it is stressed that local environmental (and to a lesser extent, cultural) conditions should dictate the precise nature of these. That said, it does seem appropriate to discuss a few of what are perhaps the most common technological solutions. The discussion below is divided into hard solutionstypically engineered solutions to specific problems - and soft solutions - those which typically adapt or restore the natural environment to a condition in which its effectiveness in resisting the impacts of climate change is maximized. Note that relocation, which is not a technological imperative in the sense of the others discussed here, is considered separately in Section 7.5.

\subsection{Hard solutions for sea-level rise}

The problem with most seawalls built along Pacific Island coasts, in connection with preventing their continued erosion, is that they are vertical and impermeable. In other words, they replace a shoreline that was gently sloping and allowed wave energy to be dissipated, particularly seawards, with a shoreline that focuses wave energy both along the base of the seawall (contributing to its undermining) and at either end of it. Further, it replaces a shoreline that was permeable, and therefore dispersed wave impact and backwash, with one that is impermeable, which also focuses wave energy, causing scour along the base of the seawall (see Fig. 4b). In some parts of the Pacific Islands, offshore coral reefs have been mined to provide the building blocks for seawalls (see Fig. 3b), something that increases shoreline exposure to wave attack.

If artificial structures are to be constructed (and there are alternatives), then as far as possible they should mimic the form and the composition of the natural shoreline they are replacing. Thus, seawalls should slope seawards, much as beaches do, and they should be permeable, perhaps comprising large boulders or smaller-sized particles held in place by artificial webbing (see Fig. 3a). Yet all such solutions are expensive to design, construct, and maintain, and are therefore realistically beyond the capacity of many localarea communities in the Pacific Islands. 


\subsection{Soft solutions for sea-level rise}

A more appropriate long-term strategy is to use natural coastal protection, commonly the (re-) planting of mangrove forests within the intertidal zone. The main advantages of mangrove reafforestation are that it is cheap, low-maintenance, and effective. A mangrove fringe of $30 \mathrm{~m}$ breadth is an effective barrier to shoreline erosion, as well as being able to shield the coast behind it from at least small amounts of sea-level rise. The disadvantage of mangrove reafforestation for many coastal communities in the Pacific Islands is that it takes a long time for a forest to grow from seedlings - as long as $25 \mathrm{yr}$ (Gilman et al. 2006, 2008).

It is also worth mentioning the practicality of conserving coral reefs and looking for ways to restore those that have been degraded. Coral-reef conservation is widely perceived in the Pacific Islands as a preoccupation of western countries rather than a practical solution to existing and future problems. There are signs that this view is changing, as the benefits of locally managed marine areas become widely known (Veitayaki et al. 2003, Cinner et al. 2006). Yet a healthy coral reef has a better chance of responding to sea-level rise (by growing upwards) and weathering periods of prolonged stress (associated with warming or increased sedimentation following heavy rain) than one which is significantly degraded, as many Pacific Island reefs have become (Hoffmann 2002, Sulu 2007).

The issue of the restoration of degraded coral reefs, particularly in an effort to restore their diversity and ecosystem productivity, has hardly been explored in the Pacific Islands region, but may in the future feature in adaptation packages for climate change.

\section{MANAGEMENT IMPERATIVES}

One of the issues that is largely not mentioned in the present study is that of management for the mitigation of climate change. Pacific Island nations have negligible greenhouse-gas emissions and cannot be regarded as having contributed significantly to the human enhancement of the greenhouse effect so, while these nations have the potential to influence international agendas on climate-change mitigation, this is not a priority for in-country management. Yet in this section I will look specifically at adaptation.

This section first addresses the management imperatives associated with particular climate-change issues, as listed in Table 2, before continuing to examine 5 cross-sectional management imperatives for adaptation to climate change in the Pacific Islands.
As shown in Table 2, management imperatives associated with increased climate variability require appropriate planning to ensure-as far as possibleno serious disruption to the food supply and appropriate water management. The latter ranges from the continued upkeep of communal water tanks in rural areas to a reduced dependency on large sources of open water (in reservoirs) that are often difficult to manage.

In order to reduce the impacts of more climate extremes, the identification of vulnerable areas should be improved through hazard mapping and zoning laws, and building standards should be enforced. The whole question of the national food and water supply should become the object of national plans, with climate change factored in, and viable contingency plans embedded.

The effects of temperature rise on agriculture can be countered to some extent by research into more appropriate crops and crop strains, which could be sponsored by governments and intra-regional advisory bodies. The conservation of coral reefs could be assisted by the enforcement of appropriate legislation, as well as the declaration of marine protected areas.

Responding to the many effects of sea-level rise is something that is best done through effective national planning. Aside from identifying the needs and opportunities for relocation, national plans can also help in the revitalization of over-exposed units in both agricultural and coastal sectors.

All such factors have been discussed before (Hay et al. 2003, Nunn \& Mimura 2006). The remainder of this section is therefore devoted to a discussion of what are considered to be the region-wide management imperatives for coping with future climate change. The first part deals with the question of 'ownership' of climate-change issues by Pacific Island nations, which is the critical step needed to confront the associated challenges effectively. The second part deals with the need for long-term planning, something that is often problematic in smaller, poorer democratic nations where new mandates may be given to governments with different agendas every few years. The third part explains the imperative of mainstreaming climate-change awareness, not only to dispel alarmism, but also to set the stage for appropriate country-wide responses to particular issues. The fourth part follows on from this by considering the specific need to empower communitylevel decision-makers to make informed decisions about the future of the environments under their stewardship. The final part considers relocation, arguing that, while much resisted, it remains the most appropriate response to many issues of climate change in the Pacific Islands. 


\section{1. 'Ownership' of climate-change responses}

For as long as Pacific Island nations (and other developing countries) depend on external sources of funding to help understand and adapt to the effects of climate change within their countries, it will continue to be a marginalized issue (Barnett 2005, Halsinaes et al. 2008). The point is not restricted to climate change, but to almost every initiative concerned with sustainable environmental development, an often-quoted phrase that has become oxymoronic in the Pacific Islands context (Nunn 2004a).

The problem is specifically that, unless Pacific Island governments begin to commit sizeable portions of their earned revenue towards climate-change adaptation (and other environmental issues), this issue will never be sustainably addressed within that country. Most of its inhabitants will continue to be uninformed about what to do about climate change and how it is likely to affect their lives in the future. External financial assistance is adequate for some degree of national capacity building, but, as seen above, this is not having the beneficial effects that sponsors of such initiatives have long hoped for. External financial assistance is also adequate for trialling particular adaptation options or for running limited-term pilot studies, but cannot substitute for nation-wide adaptation, which is what is needed now and will be increasingly needed in the next 2 decades.

Most Pacific Island governments would claim that they have insufficient funds to commit to climatechange adaptation (and more broadly, sustainable environmental development) because of competing priorities. Yet these competing priorities are often those that involve exploitation of the environment for short-term profit. The time will come within the next 10 to 20 yr when the problems associated with climate change become so acute in the Pacific that island governments will finally be forced to divert substantial amounts of their earned income to adaptation. By then this will be far more expensive and probably less effective than starting the process of self-funded national adaptation now.

International donors should acknowledge the dangers of a long-term dependency of such nations on external funding assistance to face the challenges of climate change (Barnett 2008) and encourage these nations to take increasing ownership of climate-change adaptation.

\subsection{The imperative of long-range planning}

Five-year democracies are commendable in many ways, but, especially in smaller, poorer countries, elec- torates tend to reward governments that put more money into individual pockets between elections than those-if there are any in such countries - that embrace long-term plans restricting resource use and environmental exploitation in the name of sustainable development. This is a real dilemma of democracy in smaller, poorer countries (Clague et al. 2001), and one that manifestly contributes to the difficulties in achieving global action on climate-change adaptation (Sarewitz 2004).

Minimizing the undesirable impacts of climate change in larger, wealthier countries involves long-range planning that almost all competing political alliances would agree rises above their individual agendas. But in smaller, poorer countries, like those in the Pacific Islands, while long-range development plans are issued, invariably it becomes more important to attain short-term development goals (Hassall 2008). Yet effective long-range planning is essential if the impacts of climate change on Pacific Island peoples are to be minimized in the future (Ponzi et al. 2004). Many career decision-makers in Pacific Island governments recognize this clearly, but their political masters typically overrule such decisions when the short-term consequences will be unpopular.

There is no obvious solution to this. Yet if long-term plans are not put into place and rigidly adhered to, then again the situation will likely become exigent 10 to 20 yr from now, and rapid action will have to be taken to safeguard particular communities and particular resources.

\subsection{Mainstreaming climate-change awareness}

Another important way forward involves the mainstreaming of awareness of climate change. This kind of education is merely frustrating unless you also give opportunities and, where appropriate, the tools to adapt to climate change, but it is a necessary preliminary. The people of the Pacific Islands should become more aware of what future climate change is likely to involve, precisely how it will affect presentday ways of life, and what the best options are for adaptation.

There is a huge amount of misinformation about climate change in the Pacific Islands, much of it engendered by a disingenuous media that focuses on disastrous situations and on extreme predictions of what might happen. The media could well use their considerable power in the Pacific Islands region to raise awareness about the mainstream views on climate change and to help spread awareness about successful solutions to various aspects of climate change, but they rarely do. 
Yet there are other ways of raising awareness, ways that are generally more respected among Pacific Island communities than many media sources. This could be accomplished, for example, by either information sheets or personalized verbal communication (Kuijper 2003). Community-level awareness raising is targeted in many climate-change adaptation strategies such as the Kiribati Adaptation Program of the World Bank and the increasing number of Locally Managed Marine Protected Areas (LMMAs) that are to be found in the region (Johannes 2002, Veitayaki et al. 2003, Veitayaki 2006).

Many Pacific Island communities are truly communal, in the sense that they share many tasks and activities and that individuals within those communities cooperate and communicate regularly with one another. These attributes provide excellent opportunities for mainstreaming awareness of climate change. For example, information sheets written in vernacular languages, well illustrated, culturally apt, and using familiar examples would be studied and exchanged at length among rural communities. It is also appropriate, as discussed in more detail in the following section, to empower community leaders - be they hereditary chiefs, elected spokespeople, school teachers, or church leaders - to communicate mainstream views about climate change to the people that routinely listen to them.

As a last point in this section, it is appropriate to discuss awareness raising amongst schoolchildren through the incorporation of climate-change issues in school curricula. It is important that this is done in ways that are culturally appropriate so that school children do not feel that this is an alien issue of no immediate relevance to them. But it is also important not to place too much faith in this type of awareness raising as a way of changing the attitude of Pacific Island societies towards climate change. Most such societies remain rigidly hierarchical, and children are at the bottom of the pile, generally not encouraged to speak for themselves, but to listen to and absorb the wisdom of their elders. In the Pacific Islands, creating a young generation that is far more aware of climate-change issues than their parents' and grandparents' generations will not bring about change in the position of societies on these issues as quickly as might be expected in other, less hierarchical societies.

\subsection{Empowering community-level decision makers}

As shown above, most national policies (expressed through legislation) concerning environmental management in Pacific Island countries are ineffectual, both because of a lack of enforcement and because of the conviction of landowners that they should be permitted to arrive at decisions regarding their land independently of what is perceived as outside interference. This situation is unlikely to change significantly in the next few decades, so it follows that an important way to bring about appropriate adaptation to the various manifestations of climate change is to give landowners (community-level decision-makers) the information they need to make responsible decisions about their environments.

This information involves giving sufficient explanation of the science behind climate change, supplemented by Pacific Island examples, to convince decision-makers of the need for action. Additional information should concentrate on the likely nature of present and future changes to environments, again supported by examples from similar situations. Finally, and most importantly, there should be a systematic explanation of the options available to communities for combating the undesired effects of climate change and what is involved in sustaining each option into the foreseeable future.

While community-level decision-makers could be targeted specifically, perhaps through short courses in regional centres, it is also important to disseminate information about climate-change decision-making to all communities. To localize and emphasize the importance of the climate-change issue, it seems essential to deliver the message in vernacular languages, those which are most commonly used and best understood, not only by community-level decision-makers, but also by members of the communities in particular places. The best medium would be in print, in the form of specially designed pamphlets that could be circulated within communities and mulled over at length. Printed information could be supplemented by radio and television where appropriate.

To ensure that this approach to empowering community-level decision-makers is sustained, it needs to be regularly reinforced. There are 2 principal ways in which such reinforcement could come about in the Pacific Islands context: reinforcement by the government and reinforcement through shared experiences.

Reinforcement by the government might involve refresher courses for community-level decision-makers in which they are encouraged to explain the actions that their community has taken with respect to particular problems and how effective these actions appear to have been. Reinforcement by the government might also be achieved through regular slots on radio and television, as appropriate, which would demonstrate that climate-change issues remain high on national agendas.

Reinforcement through shared experiences would involve communities talking to other communities, 
both within a particular country and between countries. This approach acknowledges the similarities, not only in environments that particular communities occupy, but also regarding the nature of competing interests to climate-change adaptation, and the tools available within communities for adaptation. Reinforcement of this kind would be important to communities debating various adaptation strategies, but also in demonstrating that action can bring about improvements.

\subsection{Relocation}

From a geological perspective, the alternate submergence and emergence of coastal lands-even entire islands - is something that is expected and unavoidable in the course of history (Nunn 1994); a good example is of Tuvalu (Dickinson 2009). Being so sanguine about this issue is of little practical help to the Pacific Island people whose homes will be submerged over the next few decades. Yet whatever resistance there will inevitably be to relocation, there is simply no alternative in most cases where coastal/lowland settlements are threatened by sea-level rise. Far-sighted decision-makers should act now to minimize future disruption.

Much has been written about the vulnerability of the lowest and most insular (measured by the insularity ratio; Nunn \& Kumar 2006) islands in the Pacific to the effects of future sea-level rise (Roy \& Connell 1991, Barnett \& Adger 2003). Atoll islands (or motu) comprise all (or most) of Pacific nations like Kiribati, the Marshall Islands, Tokelau, and Tuvalu. While armoured by beachrock and other types of naturally forming conglomerate in places, most atoll islands are formed from unconsolidated gravel and sand. Life on atolls is generally more challenging and has fewer options than on larger Pacific islands. Sea-level rise during this century has been predicted to render some such atolls uninhabitable, because of inundation, contracted water tables, and erosion. There is no doubt that atoll dwellers face serious and impending problems connected with their continued occupation of such vulnerable environments. The lack of high ground on atoll islands means that off-island relocation is the only long-term adaptation option for many. Welldocumented examples of relocation from atolls that relate the efficacy and challenges of the process for Pacific islanders come from Bikini Atoll in the Marshall Islands, from which people were moved after it became clear that atomic testing had polluted their environment (Davis 2005), and Rabi Island in Fiji, which is occupied by people displaced from Banaba in Kiribati (Kempf \& Hermann 2005).
The focus on atolls and the attendant media hype has reduced the attention paid to the probable impact of sea-level rise on other types of Pacific islands (Nunn 2004b, 2007). Yet the future of many high-island Pacific nations is threatened to an equally serious extent by sea-level rise because most of the cash-generating (as opposed to subsistence) activities of these countries are located on coastal plains, often only a few metres above sea level. Sea-level rise threatens the existence of these coastal plains. In most places higher ground exists in their hinterlands, to which coastal dwellers could relocate. Yet this is not a simple solution, largely because the complex land-tenure systems of Pacific Island countries invariably mean that coastal dwellers cannot readily move inland without negotiating difficult and unprecedented arrangements with customary landowners (Crocombe 1987); for example, in the Kingdom of Tonga, all land above the highwater mark is owned by the monarch, with lots distributed to and withdrawn from commoners at will (Halatuituia 2006).

Many coastal towns (and cities) in the (non-atoll) Pacific Island countries are experiencing increasing regular flooding during heavy rain. So unthinkable is the idea of relocation-and all the disruption and cost that would entail-that the affected people are clamouring for more dredging of nearby rivers, more upstream dams, and better seawalls. But none of these are any more than cosmetic solutions, unable to solve the problem. For such towns were originally builttypically 100 to $150 \mathrm{yr}$ ago-on flatlands for the convenience of building, in coastal locations to facilitate ship transport, and close to rivers for freshwater and access to resource-rich hinterlands. In the time since these towns were established, hinterlands have been denuded of natural vegetation cover, thereby increasing river sediment loads (Fig. 5a). These sediment loads are carried downstream, and, where stream gradients are reduced, as they are on coastal lowlands, the sediment is deposited in river channels and around their mouths. This reduces river-channel capacity, making flooding more frequent. More frequent floods are also caused by rain falling on the now-denuded catchments where there is no longer as much vegetation as there once was to slow the movement of rainwater into river channels. Added to this is the sealevel rise, which not only causes shoreline erosion of such delta fronts and coastal plains, but also causes a base-level rise, forcing river channels to aggrade and thereby reducing their capacity further. Finally, there is human impact. The weight of a coastal town compresses the unconsolidated sediments below, causing them to sink slowly, a process that is amplified by both groundwater extraction and the natural tendency of such sedimentary structures to become compacted. 

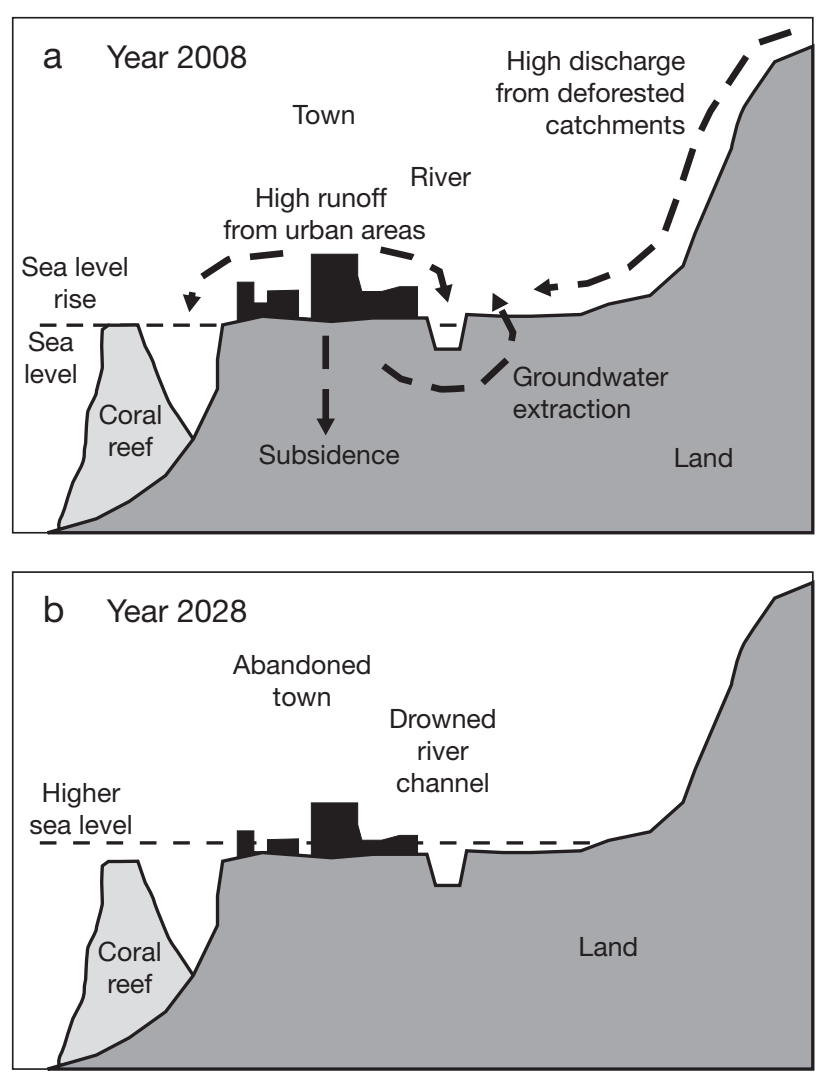

Fig. 5. Many coastal towns and cities in the Pacific Islands will not be readily inhabitable in 20 yr time. (a) By 2008, many towns had been affected by both a sea-level rise and by subsidence compared to the time they were established (perhaps $100 \mathrm{yr}$ earlier). The combination of these has caused their levels to drop relative to the sea surface, something manifested short term by increased flood frequency and magnitude. Flooding has been exacerbated in such locations by upland deforestation and detrimental agricultural practices and by high runoff from urban areas, the combination of which is to reduce river-channel capacity. (b) By the end of the 2020s, the higher sea level, combined with other factors, will have submerged many such coastal towns and cities. For poorer countries, the best long-term adaptation option is to begin relocating such towns and cities to less vulnerable areas

The construction of roads and pavements (sidewalks) also reduces the amount of rainwater (or floodwater) that can be absorbed into the ground, so much runs straight into the rivers. As the sea level rises in the future, the functions of such locations will become increasingly difficult to sustain (Fig. 5b).

In Pacific Island countries where the funds for 'bigfix' engineering solutions will never be found for all the locations where they are needed (Nunn et al. 2006), the only long-term adaptation option is relocation.

This section ends with a brief discussion of why people in the Pacific Islands-and of course elsewhere in the world-resist relocation. It is not only along coasts threatened by sea-level rise where people resist the idea of moving, but also on the slopes of active volcanoes or in the subsiding centres of deltaic cities. Principally, relocation is resisted today because modern people have become fully sedentary in ways that our ancestors were not a few hundred years ago. We have built ourselves permanent dwellings, surrounded ourselves with permanent infrastructure, and have convinced ourselves of humanity's dominion over Nature. But this is a false belief, as periodic natural disasters remind us. The Indian Ocean Tsunami on 24 December 2004 was a shock to coastal peoples throughout that part of the world, as was the 1998 Aitape Tsunami (Papua New Guinea), the 1994 Northridge Earthquake (California, USA), and the 1995 Kobe Earthquake (Japan). After the latter event, urban planners acknowledged that they had allowed inappropriate development driven by economic growth without fully acknowledging or even understanding the seismic hazards of the area (Hirayama 2000). In a similar way, coastal dwellers in the Pacific Islands have allowed themselves to be lulled into a false sense of security about the permanence of the environments they occupy. As Amata Kabua, former President of the Marshall Islands, said in 1988 at the first meeting of Pacific Island countries specifically devoted to climate change and sea-level rise: 'It is truly frightening to think that our ocean will turn against us. We have been sustained by the ocean for two millennia. It has been bountiful and continues to yield to us its bounty. We have learned that this harmony may be interrupted by the action of nations very distant from our shores. I hope that the appeal of the peoples of the Pacific can help convince the industrialized nations to discontinue their profligate contamination of the atmosphere.'

And as Tamari'i Tutangata, the Director of SPREP in 2000, reflected: 'As a ten-year-old, I used to look at the sea with awe, at the seemingly endless supply of fish that I could harvest ... now when I look at it, I wonder how far into the new millennium we will be before it overwhelms our coasts. What is there to celebrate about a new millennium if the northern group of the Cook Islands, or the many islands of Kiribati, Tokelau, Tuvalu, the Federated States of Micronesia and the Marshall Islands are about to disappear beneath the ocean?'

Unpalatable as it may appear, the only possible adaptive response to climate change in many parts of the Pacific Islands region is relocation.

\section{CONCLUSIONS: THE WAY FORWARD}

The mindset of Pacific Islands decision-makers-a microcosm of the entire globe-needs to be fundamentally changed if the Pacific Islands region is not to 
be badly affected by climate change during this century. This is the message of the 2007 IPCC Report; if something is not done urgently then human societies on the Earth will be severely impacted in a number of ways. Some larger, richer countries, long opposed to the scientific as well as the socio-economic imperatives, are now acknowledging projections of future climate changes, yet still 'global efforts to address the problem remain weak and inadequate, even as changes in climate become more serious' (from a speech of IPCC Chair, Rajendra Pachauri, at the World Economic Forum in Davos, 23 January 2008; www.ipcc.ch/ graphics/speeches/pachauri-davos-january-2008.pdf).

In a global context one might legitimately ask whether it matters at all what smaller, poorer nations like those in the Pacific Islands do or do not do with regards to climate change. This is largely a rhetorical question at one level, but at another it clearly matters profoundly to the people living in Pacific Island nations how effectively their leaders both seek to mitigate the causes of deleterious climate change on the world stage and implement appropriate adaptation measures throughout their island nations.

The achievement of the latter requires a major change in thinking about and planning for future climate change in the Pacific Islands. In particular, it requires that Pacific Island nations:

(1) take ownership of the climate-change issue as it applies to their countries, ensuring that viable and appropriate long-range plans are followed,

(2) ensure that climate-change awareness is mainstreamed within the knowledge pools of these countries, and

(3) ensure that community-level decision-makers are given the knowledge and the right tools to make informed decisions about environmental management in a world where the climate is changing at an unprecedented rate.

Circa 20 yr ago, Stephen Schneider of Stanford University, one of the world foremost climate-change scientists, admonished those governments that refused to credit predictions of 21st-century climate change and its implications for global well-being with the memorable phrase, 'not to decide now [to act on climate change] is to decide'-in other words that nations which decide not to do something about adapting to climate change are making a decision nonetheless. For several reasons, discussed above, most Pacific Island nations then chose to do nothing. In 2009, most Pacific Island nations have stuck implicitly with that decision, paying lip-service to global climate-change agendas, but declining to commit their own resources to meeting the challenge. Should they continue to stay with this course of action, as seems highly likely, then the future of the Pacific Islands region will be more difficult than it need be. It is likely that, 20 to $30 \mathrm{yr}$ from now, the impacts of climate change on the Pacific Islands will be so severe that there will be innumerable calls for external assistance.

\section{LITERATURE CITED}

Barclay K, Cartwright I (2007) Governance of tuna industries: the key to economic viability and sustainability in the western and central Pacific Ocean. Mar Policy 31:348-358

Barnett J (2005) Titanic states? Impacts and responses to climate change in the Pacific Islands. J Int Aff 59:203-219

Barnett J (2008) The effect of aid on capacity to adapt to climate change: insights from Niue. Polit Sci 60:31-47

Barnett J, Adger WN (2003) Climate dangers and atoll countries. Clim Change 61:321-337

Barnett J, Lambert S, Fry I (2008) The hazards of indicators: insights from the environmental vulnerability index. Ann Assoc Am Geogr 98:102-119

Bleakley C (2004) Review of critical marine habitats and species in the Pacific Islands region. IWP-Pacific Tech Rep 5, SPREP, Apia, Samoa

Brown MJF (1974) A development consequence: disposal of mining waste on Bougainville, Papua New Guinea. Geoforum 18:19-27

Cinner J, Marnane MJ, McClanahan TR, Almany GR (2006) Periodic closures as adaptive coral reef management in the Indo-Pacific. Ecol Soc 11: 31. Available at: www. ecologyandsociety.org/vol11/iss1/art31

Clague C, Gleason S, Knack S (2001) Determinants of lasting democracy in poor countries: culture, development, and institutions. Ann Am Acad Pol Soc Sci 573:16-41

Cowell PJ, Kench PS (2001) The morphological response of atoll islands to sea-level rise. I. Modifications to the shoreface translation model. J Coast Res 34:633-644

Crocombe RG (1987) Land tenure in the Pacific. The University of the South Pacific, Suva, Fiji

Davis JS (2005) Representing place: 'deserted isles' and the reproduction of Bikini Atoll. Ann Assoc Am Geogr 95: $607-625$

Dickinson WR (1999) Holocene sea-level record on Funafuti and potential impact of global warming on central Pacific atolls. Quat Res 51:124-132

> Dickinson WR (2009) Pacific atoll living: How long already and until when? GSA Today 19:4-10

Donner SD, Skirving WJ, Little CM, Oppenheimer M, HoeghGuldberg O (2005) Global assessment of coral bleaching and required rates of adaptation under climate change. Glob Change Biol 11:2251-2265

FAO (Food and Agriculture Organization of the United Nations) (2008) Climate change and food security in Pacific Island countries. FAO, Rome

Gilman EL, Ellison J, Jungblut V, Van Lavieren H and others (2006) Adapting to Pacific Island mangrove responses to sea level rise and climate change. Clim Res 32:161-176

Gilman EL, Ellison J, Duke NC, Field C (2008) Threats to mangroves from climate change and adaptation options: a review. Aquat Bot 89:237-250

Halatuituia SNK (2006) Tonga's contemporary land tenure system: reality and rhetoric. PhD thesis, University of Sydney

Halsinæs K, Shukla PR, Garg A (2008) Sustainable development and climate change: lessons from country studies. Clim Policy 8:202-219

Hassall G (2008) Good governance and political developments in the Pacific: Can existing concepts and institutions 
deliver security? In: Graham K (ed) Models of regional governance for Pacific Island states: sovereignty and the architecture of Pacific regionalism. University of Canterbury Press, Christchurch, New Zealand, p 161-188

Hay JE, Mimura N, Campbell J, Fifita S and others (2003) Climate variability and change and sea-level rise in the Pacific Islands region. South Pacific Regional Environment Programme, Apia, Samoa

> Hettler J, Irion G, Lehmann B (1997) Environmental impact of mining waste disposal on a tropical lowland river system: a case study on the Ok Tedi Mine, Papua New Guinea. Miner Depos 32:280-291

> Hirayama Y (2000) Collapse and reconstruction: housing recovery policy in Kobe after the Hanshin Great Earthquake. Housing Stud 15:111-128

Hoegh-Guldberg O (1999a) Climate change, coral bleaching, and the future of the World's coral reefs. Greenpeace, Amsterdam

Hoegh-Guldberg O (1999b) Coral bleaching, climate change and the future of the world's coral reefs. Mar Freshw Res 50:839-866

- Hoffmann TC (2002) Coral reef health and effects of socioeconomic factors in Fiji and Cook Islands. Mar Pollut Bull 44:1281-1293

Huffer E (2005) Governance, corruption, and ethics in the Pacific. Contemp Pac 17:118-140

Hviding E (2003) Between knowledges: Pacific studies and academic disciplines. Contemp Pac 15:43-73

Hviding E (2006) Knowing and managing biodiversity in the Pacific Islands: challenges of environmentalism in Marovo Lagoon. Int Soc Sci J 58:69-85

Hviding E, Bayliss-Smith TP (2000) Islands of rainforest: agroforestry, logging and eco-tourism in Solomon Islands. Ashgate, Aldershot

> Johannes RE (2002) The renaissance of community-based marine resource management in Oceania. Annu Rev Ecol Syst 33:317-340

Johnson M (ed) (1992) Lore: capturing traditional environmental knowledge. IDRC, Ottawa

Kempf W, Hermann E (2005) Reconfigurations of place and ethnicity: positionings, performances and politics of relocated Banabans in Fiji. Oceania 75:368-386

Kench PS, Cowell PJ (2001) The morphological response of atoll islands to sea-level rise. II. Application of the modified shoreface translation model. J Coast Res 34:645-656

Kuijper MWM (2003) Marine and coastal environmental awareness building within the context of UNESCO's activities in Asia and the Pacific. Mar Pollut Bull 47:265-272

Kumar R (2007) Problems and prospects for islands at the margins: a case study of Moturiki Island, central Fiji. In: Moriwaki H, Kawai K (eds) Global warming and Pacific Islands. Kagoshima University Research Center for the Pacific Islands, Occasional Paper 47, p 41-50

Lang XM, Wang HJ (2008) Can the climate background of western North Pacific typhoon activity be predicted by climate model? Chin Sci Bull 53:2392-2399

Lomo FF (2001) Commercial logging, subsistence livelihoods and rural development: a case study of Rufoki Village, Malaita Province, Solomon Islands. MA thesis, Department of Geography, The University of the South Pacific, Suva, Fiji

McNeill JR (1994) Of rats and men: a synoptic environmental history of the island Pacific. J World Hist 5:299-349

McNeill JR (1999) Islands in the rim: ecology and history in and around the Pacific, 1521-1996. In: Flynn DO, Frost L, Latham AJH (eds) Pacific centuries: Pacific and Pacific Rim history since the sixteenth century. Routledge, London, p 70-84
Meehl GA, Arblaster JM, Branstator GW, van Loon H (2008) A coupled air-sea response mechanism to solar forcing in the Pacific region. J Clim 21:2883-2897

Mimura N, Nunn PD (1998) Trends of beach erosion and shoreline protection in rural Fiji. J Coast Res 14:37-46

Mimura N, Nurse L, McLean R, Agard J and others (2007) Small islands. In: Parry ML, Canziani OF, Palutikof JP, van der Linden PJ, Hanson CE (eds) Climate change 2007: impacts, adaptation and vulnerability. Contribution of Working Group II to the 4 th assessment report of the Intergovernmental Panel on Climate Change. Cambridge University Press, Cambridge, p 687-716

Morrison RJ, Geraghty PA, Crowl L (eds) (1994) Science of Pacific Island peoples. Institute of Pacific Studies, The University of the South Pacific, Suva, Fiji

Nunn PD (1994) Oceanic Islands. Blackwell, Oxford

> Nunn PD (2000) Coastal changes over the past two hundred years around Ovalau and Moturiki Islands, Fiji: implications for coastal-zone management. Aust Geogr 31:21-39

Nunn PD (2003) Nature-society interactions in the Pacific Islands. Geografiska Annaler 85B:219-229

Nunn PD (2004a) Through a mist on the ocean: human understanding of island environments. Tijdschr Econ Soc Geogr 95:311-325

Nunn PD (2004b) Understanding and adapting to sea-level change. In: Harris F (ed) Global environmental issues. Wiley, Chichester, p 45-64

Nunn PD (2006) Island origins and environments. In: Baldacchino G (ed) A world of islands: a physical and human approach. Agenda, Malta, p 5-37

Nunn PD (2007) Climate, environment, and society in the Pacific during the last millennium. Elsevier, Amsterdam

Nunn PD (2009) Vanished islands and hidden continents of the Pacific. University of Hawai'i Press, Honolulu

Nunn PD, Kumar R (2006) Coastal history in the Asia-Pacific region. In: Harvey $\mathrm{N}$ (ed) Global change and integrated coastal management: the Asia-Pacific region. Springer, Berlin, p 93-116

Nunn PD, Mimura N (2006) Promoting sustainability on vulnerable island coasts: a case study of the smaller Pacific Islands. In: McFadden L, Nicholls RJ, Penning-Rowsell E (eds) Managing coastal vulnerability. Elsevier, Amsterdam, p 193-221

Nunn PD, Veitayaki J, Ram-Bidesi V, Vunisea A (1999) Coastal issues for oceanic islands: implications for human futures. Nat Resour Forum 23:195-207

Nunn PD, Keally CT, King C, Wijaya J, Cruz R (2006) Human responses to coastal change in the Asia-Pacific region. In: Harvey $N$ (ed) Global change and integrated coastal management: the Asia-Pacific region. Springer, Berlin, p 117-161

> Nunn PD, Hunter-Anderson R, Carson MT, Thomas F, Ulm S, Rowland M (2007) Times of plenty, times of less: chronologies of last-millennium societal disruption in the Pacific Basin. Hum Ecol 35:385-401

Pacific Plan (2007) The Pacific Plan for strengthening regional cooperation and integration. Available at: www. forumsec.org/UserFiles/File/Pacific_Plan_Nov_2007_version. pdf

Park W, Keenlyside N, Latif M, Stroh A, Redler R, Roeckner E, Madec G (2009) Tropical Pacific climate and its response to global warming in the Kiel climate model. J Clim 22: 71-92

Pelling M, Uitto JI (2001) Small island developing states: natural disaster vulnerability and global change. Environ Hazards 3:49-62

Ponzi D, McCauley DS, Calanog LA (2004) Pacific region environmental strategy 2005-2009, Vol II. Case studies. 
Asian Development Bank, Manila

Ravuvu AD (1988) Development or dependence. Institute of Pacific Studies, The University of the South Pacific, Suva, Fiji

Roy P, Connell J (1991) Climatic change and the future of atoll states. J Coast Res 7:1057-1075

Sarewitz D (2004) How science makes environmental controversies worse. Environ Sci Policy 7:385-403

Sofer M (1985) The dependency paradigm applied to the Fijian periphery. Singap J Trop Geogr 6:127-139

Sulu R (2007) Status of coral reefs in the Southwest Pacific. Institute of Pacific Studies, The University of the South Pacific, Suva, Fiji

Takesy A (2004) Using the churches to spread the gospel: earth's stewards of the Pacific. Islands Bus 30:46

Thistlewaite B, Davis D (1996) Pacific 2010: a sustainable future for Melanesia? Natural resources, population and development. Pacific Policy Paper 17, National Centre for

Submitted: July 23, 2008; Accepted: March 25, 2009
Development Studies, The Australian National University, Canberra

Turnbull J (2004) Explaining complexities of environmental management in developing countries: lessons from the Fiji Islands. Geogr J 170:64-77

Veitayaki J (2006) Caring for the environment and the mitigation of extreme events in Vanuaso Tikina, Gau Island, Fiji Islands: a self-help community initiative. Island Studies Journal 1:239-252

Veitayaki J, Tawake A, Aalbersberg B, Rupeni E, Tabunakawai K (2003) Mainstreaming resource conservation: the Fiji locally-managed marine area network and national policy development. In: Jaireth $\mathrm{H}$, Smyth D (eds) Innovative governance, indigenous people, local communities and protected areas. Ane Books, New Delhi, p 105-124

Wood H (2003) Cultural studies for Oceania. Contemp Pac 15:340-374

Zurick DN (1995) Preserving paradise. Geogr Rev 85:157-173

Proofs received from author(s): August 21, 2009 